\title{
Ciliate distributions and forcing factors in the Amundsen and Bellingshausen Seas (Antarctic)
}

\author{
Stephen A. Wickham ${ }^{1, *}$, Ulrike Steinmair ${ }^{1}$, Nina Kamennaya ${ }^{2}$ \\ ${ }^{1}$ Department of Organismal Biology, University of Salzburg, Hellbrunnerstr. 34, 5020 Salzburg, Austria \\ ${ }^{2}$ Department of Plant and Environmental Sciences, Hebrew University of Jerusalem, \\ Edmond J. Safra Campus, Jerusalem 91904, Israel
}

\begin{abstract}
Data for ciliate abundance, biomass and taxonomic composition, along with relevant biotic and abiotic parameters, were gathered from 9 profiles in the Bellingshausen and Amundsen Seas (Southern Ocean) during late summer and early autumn 2006. A total of 70 species were found, with extrapolations using species accumulation curves suggesting that the true diversity lay between 77 and 90 species. Ciliate abundance and biomass were low, but not unexpectedly so, given the time of year and productivity of the system. Despite the harsh environment, species richness was not less than that found for protists from more temperate habitats, and declined with depth less steeply than abundance and biomass. Ciliate biomass was driven primarily by productivity, with tighter correlations between chlorophyll $a(\mathrm{chl} a)$ and either abundance or biomass than those seen from other marine systems. Community composition was also driven by productivity, with a principal components analysis (PCA) on species data showing the first axis strongly correlated with productivity parameters. Moreover, species abundance distributions (SADs) were most often best matched by the geometric distribution, thought to be expected when relatively few parameters determine species distributions. Abundance and diversity were also compared using settled and quantitative protargol stain (QPS) samples. QPS samples had lower mean abundance, higher total species richness and higher taxonomic resolution than did the settled samples. However, per-sample species (or morphotype) richness was the same in settled and QPS samples.
\end{abstract}

KEY WORDS: Ciliate community · Antarctic species abundance Resale or republication not permitted without written consent of the publisher

\section{INTRODUCTION}

That ciliates can form a substantial proportion of planktonic biomass, and play a central role in aquatic carbon fluxes, is well established (Weisse et al. 1990, Burkill et al. 1995, Calbet \& Landry 2004). It is also apparent that there can be high taxonomic diversity among ciliates, with both endemic and cosmopolitan species (Katz et al. 2005, Doherty et al. 2007, Foissner et al. 2008). However, studies which combine quantitative abundance and biomass data with good taxonomic resolution for ciliates, particularly in the Southern Ocean, are quite rare. Petz (2005, and references cited therein) list a total of 161 ciliate species found in the Southern Ocean from various studies, time periods and habitats, and while the taxonomic resolution is outstanding, it is not possible to obtain an idea of which species are dominant and which are rare. Moreover, many studies on ciliates of the Southern Ocean have concentrated on sea-ice or ice-edge communities (e.g. Garrison \& Buck 1989, Song \& Wilbert 2000, Garrison et al. 2005). On the other hand, total ciliate abundance or biomass has often been calculated, but taxonomic resolution often has not gone beyond that of tintinnids or oligotrichs (e.g. Garrison et al. 1993, Edwards et al. 1998, Froneman 2004, Santoferrara \& Alder 2009). The lack of taxonomic detail can result in the loss of ecologically relevant information, as ciliates can fill the functional roles of autotrophs, mixotrophs and heterotrophs-grazing particles from picoplankton to 
large diatoms - and are themselves consumed by predators ranging from dinoflagellates to krill (Sanders 1991, Sanders \& Wickham 1993, Stoecker et al. 1995, Christaki et al. 1999, Wickham \& Berninger 2007). Using settled samples fixed with Lugol's solution or Bouin's solution to enumerate ciliates can be a hindrance to better taxonomic resolution, as, in these samples, it is often difficult to identify the small aloricate ciliates which often dominate pelagic communities (Garrison et al. 1993, Claessens et al. 2008).

In order to better characterize both the pelagic ciliate community of the Southern Ocean and the factors that influence its size and composition, samples for ciliates and other biotic and abiotic parameters were taken in 9 profiles during the late austral summer in 2006 in the Bellingshausen and Amundsen Seas. While a descriptive study cannot definitively assign causes to observed distributions, we used a number of approaches to at least generate hypotheses about putative community and biomass drivers. For one, we correlated abundance and biomass data against a number of biotic and abiotic parameters to determine associations. We also conducted regressions of species richness against chlorophyll a ( $\mathrm{chl} \mathrm{a)}$ and ciliate biomass to determine whether these relationships were similar to those found for ciliates from different habitats. In addition, we compared estimates of species richness and abundance obtained by counting settled samples with those from the quantitative protargol stain (QPS) which offers higher taxonomic resolution (Montagnes \& Lynn 1987). In order to determine how close the species richness estimates were to the true species richness, species accumulation curves were calculated (Colwell \& Coddington 1994). The response of the ciliate community, at the species level, to varying environmental conditions was examined using principal components analysis (PCA), correlating the generated axes against the measured environmental parameters. Finally, there has been recent interest in whether Hubbell's (2001) neutral theory of biodiversity applies to ciliates, and what, if anything, this says about how ciliate communities are assembled (Dolan et al. 2007, Claessens et al. 2010). Hubbell's model suggests that communities are random assortments of competitively similar species governed by random processes of recruitment from a larger metacommunity, speciation and extinction (Hubbell 2001). While so-called species abundance distribution (SAD) curves can have multiple theoretical causes, communities conforming to the neutral theory are thought to show either the zero-sum multinomial distribution, or, if species are not dispersal limited, the log-series distribution (Hubbell 2001, McGill et al. 2007). In contrast, a geometric distribution is thought to occur when only a few environmental parameters are driving species distributions, such as in harsh environments (Magurran 1988). By using these varied approaches, we attempted to provide a more complete picture of the ciliate community of the Southern Ocean - during a part of the year that has received relatively little attention: the late austral summer and early autumn.

\section{MATERIALS AND METHODS}

Profiles were taken as part of the ANT XXIII/4 cruise of RV 'Polarstern' during the period February 16 to March 26, 2006. The research area was the Bellingshausen and Amundsen Seas, west of the Antarctic Peninsula, between $69^{\circ} \mathrm{W}$ and $125^{\circ} \mathrm{W}$ and between $68^{\circ} \mathrm{S}$ and $72^{\circ} \mathrm{S}$. Stns P1 to P4 were located on an east-to-west transect from the west coast of the Antarctic Peninsula to Peter I Island: from $68^{\circ} 12^{\prime} \mathrm{S}$, $69^{\circ} 48^{\prime} \mathrm{W}$ to $68^{\circ} 43^{\prime} \mathrm{S}, 90^{\circ} 5^{\prime} \mathrm{W}$ (Fig. 1, Table 1). Profile P1 was taken on the continental shelf in $496 \mathrm{~m}$ depth, P2 on the shelf break, and P3 and P4 in the open ocean (Table 1). The next 5 profiles were more scattered, but they also featured stations on the continental shelf, on the shelf slope and in the open ocean. The minimum water depth was $276 \mathrm{~m}$ in Pine Island Bay (P5), the maximum depth $3447 \mathrm{~m}$ (P3). Stn P7 was on the continental shelf slope near Thurston Island. Stn P9, while in the open ocean, was above the Marie Byrd Seamounts, and therefore in somewhat more shallow water. The dates, depths and locations of the sampling stations are given in Table 1. When the water depth allowed, samples were taken at $20 \mathrm{~m}$ intervals from the surface to

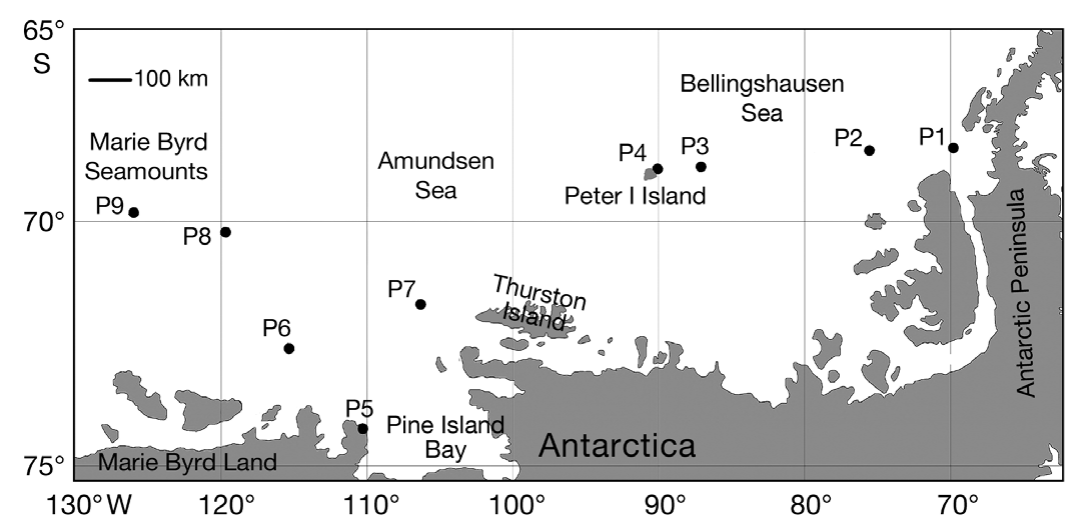

Fig. 1. Sampling stations P1 to P9 during the RV 'Polarstern' cruise ANT XXIII/4, from February 16, 2006 (Stn P1) to March 26, 2006 (Stn P9) in the Bellingshausen and Amundsen Seas, Antarctica 
Table 1. Summary of the 9 profiles sampled during cruise ANT XXIII/4. The depths $0-180 \mathrm{~m}$ were sampled at $20 \mathrm{~m}$ intervals

\begin{tabular}{|lccccc|}
\hline Profile & $\begin{array}{c}\text { Date } \\
(\mathrm{dd} / \mathrm{mm} / \mathrm{yy})\end{array}$ & $\begin{array}{c}\text { Water depth } \\
(\mathrm{m})\end{array}$ & $\begin{array}{c}\text { Sample depths } \\
(\mathrm{m})\end{array}$ & $\begin{array}{c}\text { Latitude } \\
(\mathrm{S})\end{array}$ & $\begin{array}{c}\text { Longitude } \\
(\mathrm{W})\end{array}$ \\
\hline P1 & $16 / 02 / 06$ & 496 & $0-180,300,400,480$ & $68^{\circ} 12.10^{\prime}$ & $69^{\circ} 48.34^{\prime}$ \\
P2 & $17 / 02 / 06$ & 1080 & $0-180,300,500$ & $68^{\circ} 16.08^{\prime}$ & $75^{\circ} 33.32^{\prime}$ \\
P3 & $18 / 02 / 06$ & 3447 & $0-180,300,500$ & $68^{\circ} 40.80^{\prime}$ & $87^{\circ} 6.12^{\prime}$ \\
P4 & $18 / 02 / 06$ & 2964 & $0-180,300,500$ & $68^{\circ} 43.94^{\prime}$ & $90^{\circ} 5.04^{\prime}$ \\
P5 & $01 / 03 / 06$ & 276 & $0-180,250$ & $74^{\circ} 19.73^{\prime}$ & $110^{\circ} 16.15^{\prime}$ \\
P6 & $10 / 03 / 06$ & 600 & $0-180,300,500$ & $72^{\circ} 46.36^{\prime}$ & $115^{\circ} 19.25^{\prime}$ \\
P7 & $18 / 03 / 06$ & 1520 & $0-180,300,500$ & $71^{\circ} 0.05^{\prime}$ & $105^{\circ} 39.67^{\prime}$ \\
P8 & $22 / 03 / 06$ & 2887 & $0-180,300,500$ & $70^{\circ} 15.04^{\prime}$ & $119^{\circ} 41.22^{\prime}$ \\
P9 & $26 / 03 / 06$ & 1590 & $0-180,300,500$ & $69^{\circ} 47.37^{\prime}$ & $125^{\circ} 58.51^{\prime}$ \\
\hline
\end{tabular}

brate the chlorophyll measurements from the fluorometer on the CTD, using the regression:

$$
\begin{gathered}
\text { Chla }=0.724 \times \text { Chla }_{\text {fluor }}-0.024 \\
\left(\mathrm{R}^{2}=0.91, \mathrm{p}<0.0001\right)
\end{gathered}
$$

where Chla is the concentration of chl a measured with acetone extraction (assumed to be the 'true' concentration of chl a) and Chla fluor $_{\text {is the }}$ value of chl a measured by the fluorometer.

Ciliates were identified using standard literature (Kofoid \& Campbell 1929, Adler 1999, Petz 1999, 2005) as

$180 \mathrm{~m}$, as well as at $300 \mathrm{~m}$ and $500 \mathrm{~m}$, giving a total of 12 samples per profile. The sampling device was a SeaBird SBE 911+ CTD rosette equipped with a Dr. Haardt fluorometer and twenty-four 121 Nisken bottles as well as sensors for conductivity, pressure and temperature (CTD). A total of 108 samples were taken from 9 profiles. At the end of each profile, samples were taken immediately for ciliates, dinoflagellates, nanoplanktonic flagellates, bacteria and nutrients. For ciliates and dinoflagellates, $950 \mathrm{ml}$ was drawn off, fixed with $50 \mathrm{ml}$ of Bouin's solution, and later concentrated $10 \times$ by sedimentation; counting was carried out in settling chambers on an inverted microscope (100 to $500 \mathrm{ml}$ of the original sample). For 55 samples (all depths in profiles P1 to P5, and 2 depths each from P5 to P9), subsamples were also silver stained using the QPS methodology for identification to genus or species level (Skibbe 1994). $100 \mathrm{ml}$ samples for flagellates were fixed with glutaraldehyde ( $2 \%$ final conc.), but damage in transport made the majority of the samples uncountable. $2 \mathrm{ml}$ samples were taken for bacteria, fixed in $2 \%$ (final conc.) glutaraldehyde and stored in liquid nitrogen. Both heterotrophic and autotrophic prokaryotes were enumerated by flow cytometry after staining with Cyber green (Marie et al. 2001). Dissolved phosphorus and oxygenated dissolved nitrogen $\left(\mathrm{NO}_{2}^{-}+\mathrm{NO}_{3}{ }^{-}\right)$were measured spectrophotometrically with a QuikChem 8000 flow injection analyser (Lachat Instruments). Concentrations of ammonium were determined by the orthophthaldialdehyde method (Holmes et al. 1999) and quantified by fluorescence detection on a TBS-380 mini-fluorometer (Turner BioSystems) calibrated with the standard curve of a wide range. Concentrations of chl a were measured in sea water, prefiltered through a $100 \mu \mathrm{m}$ mesh, from 101 samples. The chl a was extracted from samples of $250 \mathrm{ml}$, collected on GF/F filters, extracted in $90 \%$ acetone for $24 \mathrm{~h}$ at $4^{\circ} \mathrm{C}$ and measured on a TBS-380 fluorometer. These chlorophyll measurements were used to cali- well as a number of original papers (Lynn \& Montagnes 1988, Lynn et al. 1988, Lynn \& Gilron 1993, Agatha \& Riedel-Lorje 1997, Suzuki \& Song 2001, Modeo et al. 2003, Agatha et al. 2005, Skovgaard \& Legrand 2005). Dinoflagellates were identified using McMinn \& Scott (2005) and Steidinger \& Tangen (1977). Ciliate abundance was converted to biovolume by measuring between 1 (for species with a single occurrence) and 10 individuals per species from the settled samples and applying standard geometric formulae or combinations thereof (e.g. for many Strombidium species, a half-sphere on top of a cone). Biovolume was then converted to biomass using a factor of 0.14 pg C $\mathrm{mm}^{3}$ (Putt \& Stoecker 1989).

Ciliate and dinoflagellate data were analysed using correlations, regressions, and PCA with the programs JMP, SAS and CONOCO (Ter Braak 1986, SAS Institute 1989). The PCA was conducted on the QPS samples, as these had greater taxonomic resolution than the settled samples counted with an inverted microscope. SADs were fitted using relative abundances and compared to the theoretical geometric, log-normal, log-series, and zero-sum multinomial (zsm) distributions. The geometric distribution was calculated according to Magurran (1988), the log-series by using May's (1975) approximation and the log-normal by using the means and standard deviation of per-species ln(abundance) in each sample to generate 1000 lognormal distributions for each sample, with species richness equal to the actual species richness in the sample. The zsm distribution was calculated using the optimal.theta and rand.neutral functions of the untb package in R (Harkin 2009). The goodness of fit of the distributions was ranked using the Akaike Information Criterium (AIC), as calculated in Dolan et al. (2007). Species accumulation curves, which estimate the total species richness from the increase in richness as samples are consecutively added together, were calculated using the specaccum function of the vegan package in R (Oksanen et al. 2009). 


\section{RESULTS}

\section{Environmental conditions}

In addition to low temperatures, the stations were characterised by low algal biomass and nutrient concentrations, a shallow mixed layer, and beneath $\sim 200 \mathrm{~m}$, a relatively warm, high-density layer. The mixed layer (defined as depths with a water density within $0.125 \mathrm{~kg} \mathrm{~m}^{-3}$ of that at the surface, Levitus 1982) had an average depth of $53 \mathrm{~m}$ (range: 14 to $165 \mathrm{~m}$ ) and a median temperature of $-1.1^{\circ} \mathrm{C}$ (range: -1.7 to 1.9 ). Beneath the mixed layer there was often a colder layer extending to $\sim 150 \mathrm{~m}$, and beneath that, a warmer, denser layer (median temperature and salinity, $1.7^{\circ} \mathrm{C}$ and 34.7, respectively; Fig. 2). In the mixed layer, chl a was generally low, with a median value of $0.36 \mu \mathrm{g}$ chl a $1^{-1}$, although surface values in profiles P2 and P3 were over an order of magnitude higher, with maximum val-

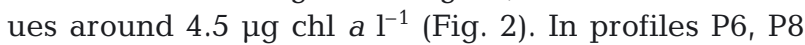
and P9 there was evidence of at least a small subsurface chlorophyll maximum, but no deeper than $\sim 80 \mathrm{~m}$. Total dissolved nitrogen within the mixed layer had a median of $19.8 \mu \mathrm{g} \mathrm{l}^{-1}$, with an N:P ratio of 11.6 . Bacterial and picoautotroph abundance in the mixed layer was low (median values: $0.21 \times 10^{6}$ and 770 cells ml$^{-1}$, respectively). In the cold layer beneath the mixed zone values were even lower $\left(0.12 \times 10^{6}\right.$ bacteria $\mathrm{ml}^{-1}$ and 410 picoautotrophs $\mathrm{ml}^{-1}$ ), and lower still in the deepest samples $\left(0.081 \times 10^{6}\right.$ bacteria $\mathrm{ml}^{-1}$ but 570 picoautotrophs $\left.\mathrm{ml}^{-1}\right)$.

\section{Ciliate abundance and biomass patterns}

Calculated over all depths and samples, median cil-

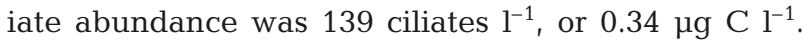
This was not distributed evenly over all depths, with both abundance and biomass concentrated in the surface layers (Fig. 3). In the mixed layer, median abundance and biomass were 452 ciliates $\mathrm{l}^{-1}$ and 0.82 $\mu \mathrm{g} \mathrm{Cl}^{-1}$, in the mid depths 147 ciliates $\mathrm{l}^{-1}$ and $0.40 \mu \mathrm{g}$ $\mathrm{C}^{-1}$, and in the deep layer 33 ciliates $\mathrm{l}^{-1}$ and $0.06 \mu \mathrm{g}$ $\mathrm{C}^{-1}$ (Table 2). Maximum abundance was 2140 ciliates $\mathrm{l}^{-1}$ while maximum biomass was $4.55 \mu \mathrm{g} \mathrm{C}^{-1}$. In the mid depths, ciliate biomass was roughly equal to that of dinoflagellates (not differentiating between autotrophic, mixotophic and heterotrophic species). In the mixed layer, however, dinoflagellate biomass was usually twice that of ciliate biomass, and in the deep layers, 3 times greater than ciliate biomass. The relative biomass proportions were highly variable, with some samples in which ciliates made up almost $100 \%$ of the combined ciliate-dinoflagellate biomass, even in the deep layers.
Total ciliate abundance and biomass, as well as species richness, were strongly correlated with a number of environmental parameters. These parameters were often correlated among themselves, the degree to which can be seen as the angle between the environmental vectors in Fig. 4, where an angle of $90^{\circ}$ represents zero linear correlation, and $0^{\circ}$ or $180^{\circ}$ perfect positive or negative correlations. Abundance, biomass and richness were positively related to productivity, measured as chl a (Table 3). In all 3 cases, the relationship was log-linear, with the following equations describing the data:

$$
\begin{gathered}
\ln (\text { ciliate abundance })=6.80+1.18 \times \ln (\mathrm{chl} a) \\
\left(\mathrm{R}^{2}=0.48, \mathrm{p}<0.0001\right) \\
\ln (\text { ciliate biomass })=0.88+1.19 \times \ln (\mathrm{chl} a) \\
\left(\mathrm{R}^{2}=0.47, \mathrm{p}<0.0001\right)
\end{gathered}
$$

and

$$
\begin{gathered}
\ln (\text { species richness })=2.82+0.27 \times \ln (\operatorname{chl} a) \\
\left(\mathrm{R}^{2}=0.26, \mathrm{p}<0.0001\right)
\end{gathered}
$$

in which ciliate abundance is in cells $\mathrm{l}^{-1}$, biomass in $\mu \mathrm{g}$ $\mathrm{C}^{-1}$ and chlorophyll $\mathrm{a}$ in $\mu \mathrm{g} \mathrm{chl} \mathrm{a}^{-1}$.

The difference in slopes of the equations (1.18 for abundance, 1.19 for biomass but 0.27 for richness) indicates that abundance and biomass increased more steeply with increasing productivity than did species richness. This trend can also be seen in the regression of species richness against abundance:

$$
\begin{gathered}
\ln (\text { richness })=0.815+0.387 \times \ln (\text { abundance }) \\
\left(\mathrm{R}^{2}=0.67, \mathrm{p}<0.0001\right)
\end{gathered}
$$

The greater dependence of abundance and biomass on productivity, compared to species richness, resulted in abundance and biomass decreasing with depth more rapidly than species richness (Fig. 3). The ratio of

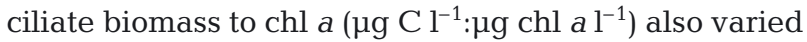
with depth and was generally low. In the mixed layer, the ratio was 2.1, while the ratio was marginally higher in the mid depths (2.6) and considerably lower in the deep layers (0.6).

Total ciliate abundance was also strongly positively correlated with bacterial abundance and negatively correlated with depth and salinity (Table 3). Chl $a$ and bacterial abundance were themselves positively correlated, and, in turn, negatively correlated with depth and salinity $\left(\left|r_{s}\right|>0.65\right.$, Table 3$)$. Species richness was related to bacterial abundance, depth and salinity in a manner similar to abundance, although the relationships tended to be weaker than for abundance $\left(\mathrm{r}_{\mathrm{s}}=\right.$ 0.53 to $r_{\mathrm{s}}=-0.44, \mathrm{p}<0.013$ ). Both ciliate abundance and species richness were largely unrelated to picoautotroph abundance $\left(\mathrm{r}_{\mathrm{s}}<0.2, \mathrm{p}>0.04\right.$, Table 3$)$.

$\mathrm{NO}_{2}{ }^{-}+\mathrm{NO}_{3}{ }^{-}$and $\mathrm{PO}_{4}{ }^{3-}$ were negatively correlated with chl $a\left(\mathrm{r}_{\mathrm{s}}=-0.53\right.$ and $\mathrm{r}_{\mathrm{s}}=-0.51$, respectively, $\mathrm{p}<$ 
Temperature $\left({ }^{\circ} \mathrm{C}\right)$ and chlorophyll a $\left(\mu \mathrm{g} \mathrm{I}^{-1}\right)$
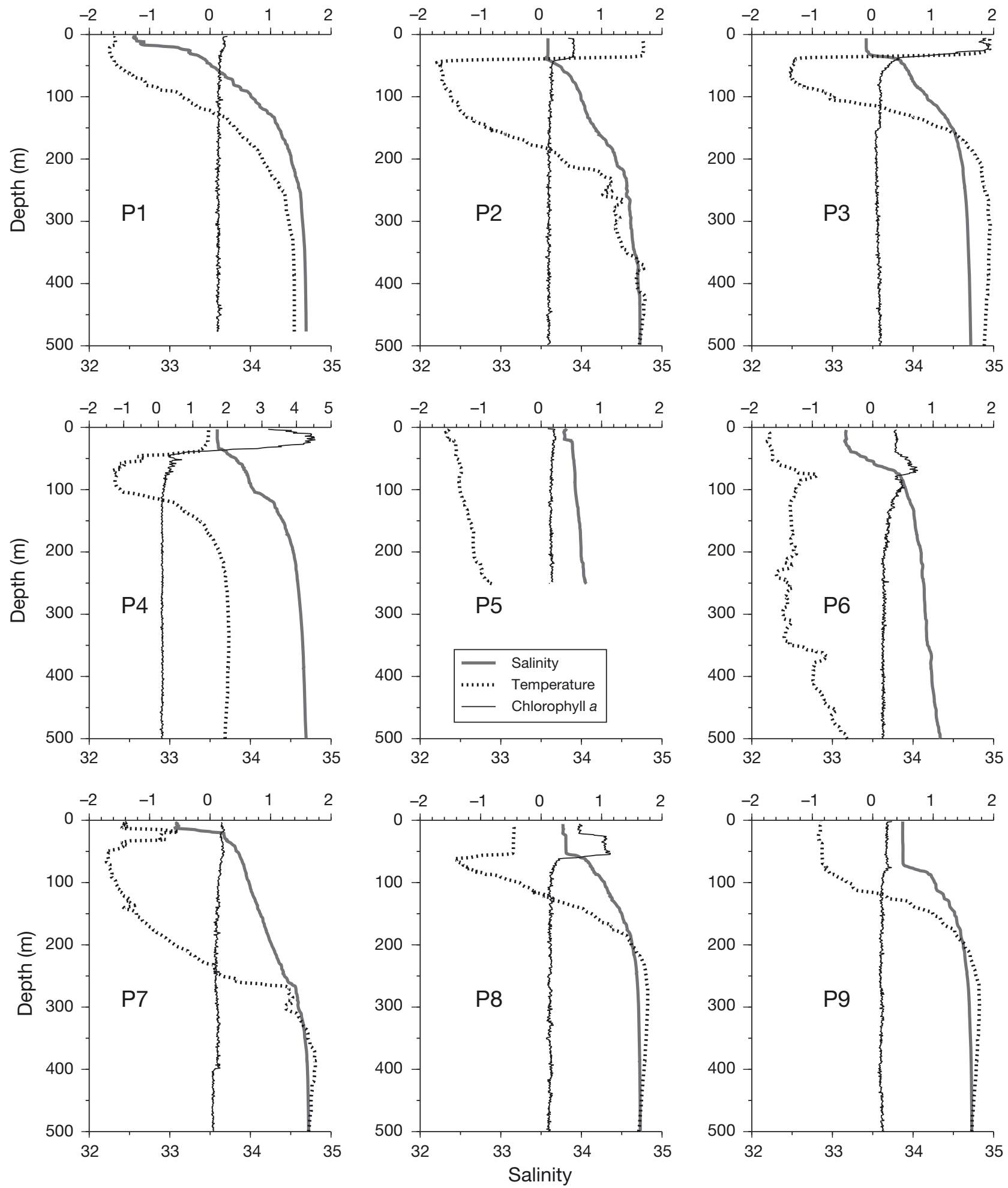

Fig. 2. Temperature, chlorophyll a ( $\mathrm{chl} a)$ and salinity profile for the 9 stations (P1 to P9) of the study. Measurements were taken with a SeaBird SBE 911+ CTD rosette and a Dr. Haardt fluorometer. Values of chl a were corrected using values derived from samples analysed with acetone extraction (see 'Materials and methods'). Note that the maximum value on the temperature/ chlorophyll scale for profile P4 is 5, while on all other panels it is 2. Maximum depth in profile P5 was $276 \mathrm{~m}$, resulting in a truncated profile 

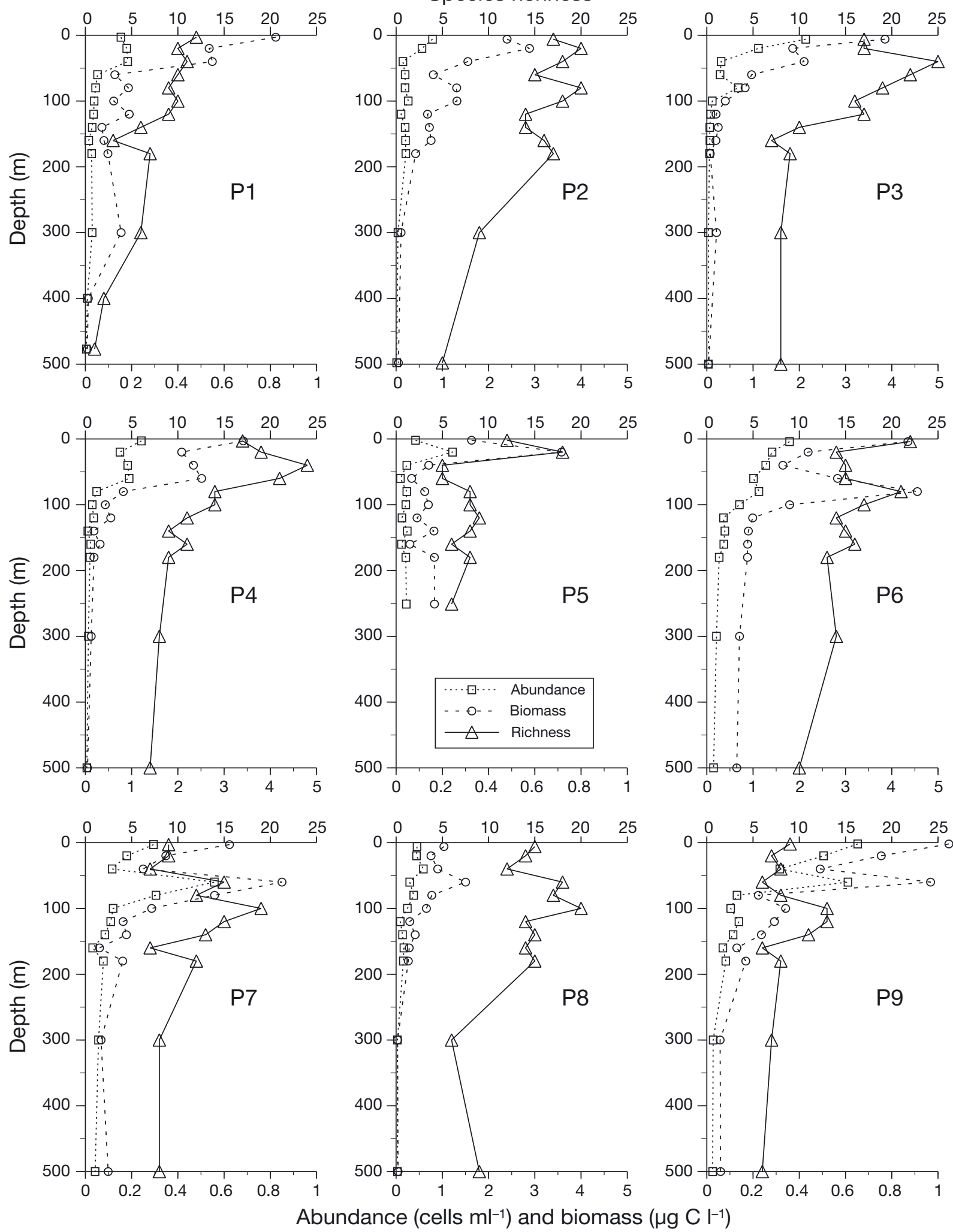

Fig. 3. Ciliate species richness, abundance and biomass for the 9 stations (P1 to P9) of the study. Abundance is given in cells ml ${ }^{-1}$ while biomass is in $\mu \mathrm{g} \mathrm{Cl}^{-1}$ in order to present abundance and biomass on the same scale. Note that the maximal value for abundance and biomass is 1 for profiles P1, P5, P7 and P9, while it is 5 in the remaining panels. Maximum depth in profile P5 was 
Table 2. Median ciliate abundance, biomass and species richness for the mixed layer (where density was within $0.125 \mathrm{~kg}$ $\mathrm{m}^{-3}$ of the surface density), the mid layer (from the bottom of the mixed layer to $180 \mathrm{~m}$ depth) and the deep layer (all samples from $>180 \mathrm{~m}$ depth). Values in brackets are the abundance, biomass and species richness ranges

\begin{tabular}{|c|c|c|c|}
\hline Layer & $\begin{array}{l}\text { Abundance } \\
\left(\text { cells } 1^{-1} \text { ) }\right.\end{array}$ & 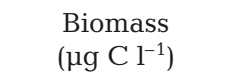 & Richness \\
\hline Mixed & $452.6(18.9-2139.0)$ & $0.82(0.06-4.35)$ & $15(6-22)$ \\
\hline Mid & $147.4(14.7-1126.3)$ & $0.40(0.06-4.55)$ & $11(3-25)$ \\
\hline Deep & $32.6(4.2-208.4)$ & $0.06(0.01-0.72)$ & $8(4-9)$ \\
\hline
\end{tabular}

0.0001) and perhaps, as a result, there were also negative correlations with these nutrients and ciliate abundance and species richness, although the relationship was stronger for abundance than for richness (Table 3). While $\mathrm{NH}_{4}{ }^{+}$was not related to chl a $\left(\mathrm{r}_{\mathrm{s}}=0.19, \mathrm{p}=0.15\right)$, there was still a positive correlation with ciliate abundance, and, in particular, species richness. The N:P ratio, however, was not related to either abundance or richness (Table 3).

\section{Ciliate taxonomic patterns}

A total of 70 ciliate and 15 dinoflagellate species or morphotypes (which could be distinguished, but not identified to species) could be identified in the samples. Ciliate species richness ranged from 25 to 3 species at any depth in the profiles. Species richness was similar in the mixed and mid layers, despite ciliate

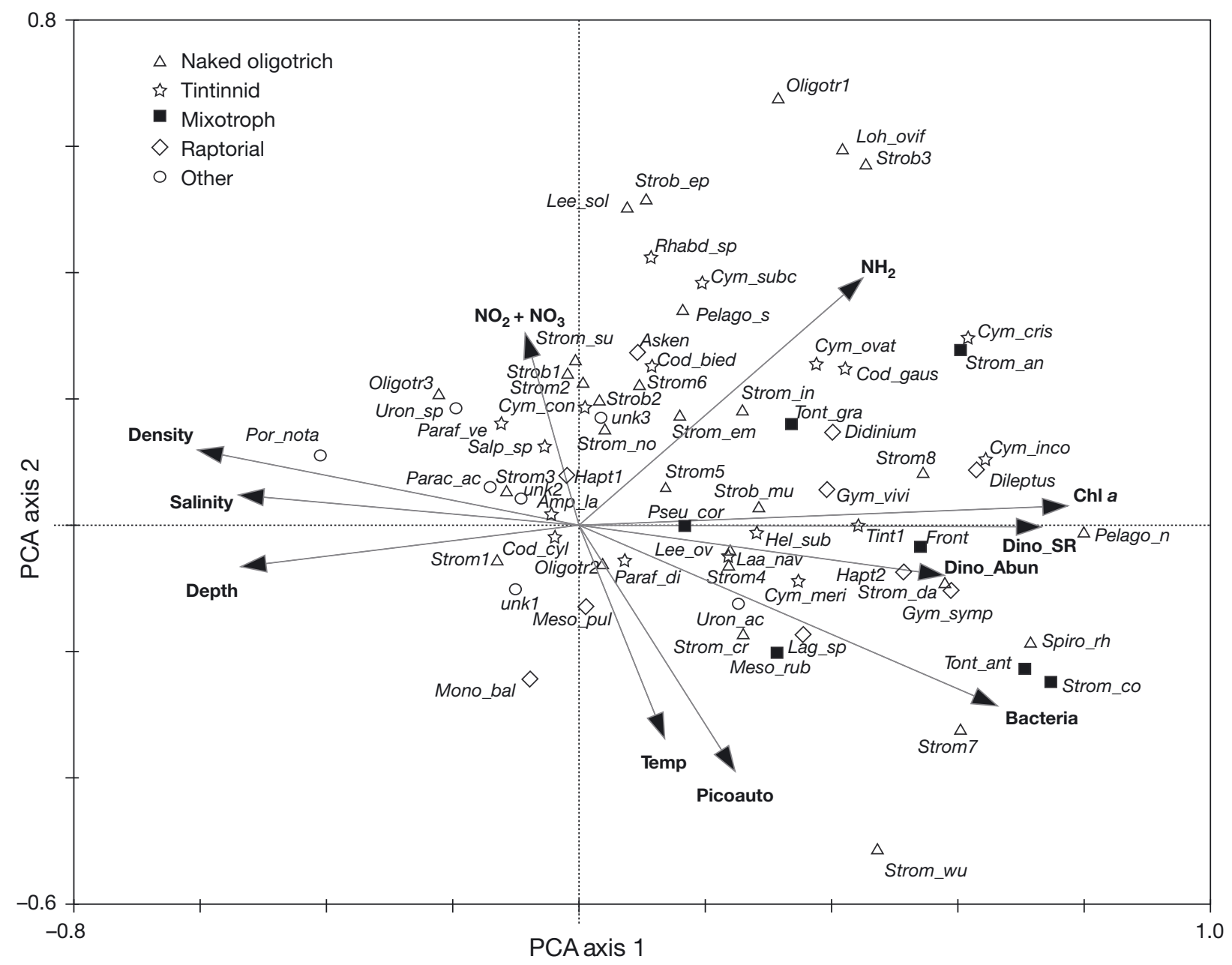

Fig. 4. Results of the principal components analysis (PCA) of the ciliate data, overlaid with the correlations between the PCA scores and the environmental factors potentially influencing the ciliate distributions. The $x$-axis is the first PCA axis, the $y$-axis is the second PCA axis. Symbols: ciliate species, broken into taxonomic and functional groups. Abbreviations are expanded in Table 4. Arrows: Pearson correlation coefficients between the PCA axes and the environmental factors, where the length and direction of the arrow gives the correlation with the 2 axes (e.g. chl a had a correlation of 0.77 with PCA axis 1, and 0.03 with PCA axis 2). The angle between the environmental factors gives the degree of correlation among the factors, with $0^{\circ}$ indicating $\mathrm{r}=1.0,90^{\circ} \mathrm{r}=0$, and $180^{\circ} \mathrm{r}=-1$. Dino_SR = dinoflagellate species richness; Dino_Abun = dinoflagellate abundance; Picoauto $=$ picoautotroph abundance; Temp = temperature 
Table 3. Spearman (non-parametric) correlations of ciliate total biomass and species richness with the environmental parameters measured. For each parameter, the Spearman correlation coefficient (Coeff.) and the probability (p) that the correlation is not different from 0 are shown. Because ciliate abundance and biomass were closely correlated $\left(r_{S}=0.95\right)$, only the biomass values are given

\begin{tabular}{|c|c|c|c|c|}
\hline \multirow[t]{2}{*}{ Parameter } & \multicolumn{2}{|c|}{ Biomass } & \multicolumn{2}{|c|}{ Richness } \\
\hline & Coeff. & $\mathrm{p}$ & Coeff. & $\mathrm{p}$ \\
\hline Chlorophyll a & 0.74 & $<0.0001$ & 0.53 & 0.0001 \\
\hline Temperature & -0.35 & 0.0002 & -0.27 & 0.044 \\
\hline Salinity & -0.69 & $<0.0001$ & -0.44 & 0.0007 \\
\hline Depth & -0.67 & $<0.0001$ & -0.43 & 0.001 \\
\hline $\mathrm{PO}_{4}{ }^{3-}$ & -0.40 & 0.0001 & -0.38 & 0.009 \\
\hline $\mathrm{NO}_{2}^{-}+\mathrm{NO}_{3}^{-}$ & -0.43 & $<0.0001$ & -0.13 & 0.36 \\
\hline $\mathrm{NH}_{4}^{+}$ & 0.43 & $<0.0001$ & 0.52 & 0.0002 \\
\hline $\mathrm{N}: \mathrm{P}$ & -0.05 & 0.65 & 0.26 & 0.074 \\
\hline Bacteria & 0.77 & $<0.0001$ & 0.34 & 0.012 \\
\hline Picoautotrophs & 0.23 & 0.018 & 0.06 & 0.69 \\
\hline
\end{tabular}

abundance and biomass in the mid depths being considerably lower than in the mixed layer (Table 2, Fig. 3). A median of 15 species (range: 6 to 22) were found in the mixed layer, with 11 species in the mid depths (range: 3 to 25, summed over all depths in the layer). The mixed layer had approximately twice the biomass and 3 times the abundance of the middle depths (Table 2), but more samples were usually taken in the mid depths, thus increasing the probability of finding rare species. While samples beneath $180 \mathrm{~m}$ had the lowest abundances (median: 33 ciliates ${ }^{-1}$, range: 4 to 208 ciliates $\mathrm{l}^{-1}$ ), species richness was relatively high, with a median of 8 species found (Table 2). Unlike the relatively high species richness in the mid layers, the species richness in the deep samples was unlikely to be due to a sampling effect, as there were only 1 to 3 samples from these depths, compared to 2 to 8 samples in the mid layers and 1 to 9 samples in the mixed layer.

Despite the low number of samples from deeper waters, it would appear that a higher sampling intensity would have revealed only a limited number of additional species. With 55 samples where the taxonomic resolution was good, we could construct species accumulation curves to estimate the total number of ciliate species in our study area. The estimated total number of species varied with the method used (Chao, Jackknife or Bootstrap) but the estimates ranged between 77 (Bootstrap) and 90 (Jackknife) species, with standard errors in the range of 8.6 to 2.7 species. This compares favourably to the 70 species actually found.

In all samples, the dominant ciliate group were the aloricate choreotrichs and oligotrichs (hereafter referred to collectively as 'naked oligotrichs'), in terms of abundance, biomass and species richness. Naked oligotrichs made up on average $56 \%$ of the total abun- dance, and $70 \%$ of the total biomass, a proportion that was roughly constant over depths. Tintinnids were on average $16 \%$ of total abundance and $9 \%$ of total biomass, while raptorial litostomes (primarily Didinium gargantua, Gymnozoum viviparum and an unidentified haptorid; Table 4 ) were $8 \%$ and $5 \%$ of abundance and biomass, respectively. Mixotrophic ciliates (primarily Mesodinium rubrum and Strombidium antarcticum) made up on average $15 \%$ of total abundance, with the percentage being higher in the mixed layer than in the mid or deep layers $(20,13$ and $10 \%$ of total abundance, respectively). There was a group of 12 species that appeared in at least 20 of the 55 QPS samples (Table 4). Most common among these were the naked oligotrichs Lohmanniella oviformis, Leegaardiella sol, Strombidium antarcticum, Leegaardiella ovalis and the tintinnid Amphorides laackmanni. Conversely, there were 14 species, including what appear to be new haptorid and Strombidium species, which appeared in only a single sample (Table 4).

PCA was used to examine relationships between individual species and the environmental parameters. Dinoflagellate total abundance and species richness were included as environmental parameters, as dinoflagellates can be simultaneously prey for, competitors with, and predators on, ciliates, and they were therefore likely to influence ciliate distributions (Hansen 1991, Levinsen \& Nielsen 2002, Johnson et al. 2003). The analysis showed that, while ciliate species could be clearly separated along environmental axes, the separation was much more of a continuum than distinct groups with clear discontinuities between them (Fig. 4). The first PCA axis was a depth-productivity axis, with a strong positive correlation to chl a (r $=0.77$ ) and negative correlations to depth, salinity (with a tendency to increase with depth in Antarctic waters in the summer and early autumn, Fig. 2), and water density ( $\mathrm{r}=-0.52,-0.53$ and -0.60 , respectively). The species with the most negative value on this axis, Propostoma notatum, was found at a mean depth of $149 \mathrm{~m}$ and with a mean abundance-weighted chlorophyll concentration of $0.22 \mu \mathrm{g} \mathrm{l}^{-1}$, while Pelagostrobilidium neptuni, at the positive end of the axis, was found at a mean depth of $35 \mathrm{~m}$ with a mean chlorophyll concentration of $2.67 \mathrm{\mu g} \mathrm{l}^{-1}$ (Fig. 4, Table 2). Dinoflagellate abundance and, in particular, species richness were closely correlated with chl $a$, and explained little variance in the ciliate distribution not already explained by chl a (Fig. 4).

The second PCA axis was mostly a nutrient axis, with positive correlations to $\mathrm{NH}_{4}{ }^{+}$and $\mathrm{NO}_{2}{ }^{-}+\mathrm{NO}_{3}{ }^{-}(\mathrm{r}=0.30$ and $\mathrm{r}=0.39$, respectively) and negative correlations to picoautotroph abundance as well as temperature $(\mathrm{r}=$ -0.39 and $r=-0.34$, Fig. 4). There was no indication that mixotrophic ciliates grouped together along this 
Table 4. Summary of ciliate species ranked by their frequency of occurrence. $\mathrm{N}$ is the number of samples in which the species occurred, mean depth and mean chl $a$ are the means of the depths and chlorophyll a concentrations at which the species were found, weighted by the abundance at each depth or chlorophyll concentration. Abbreviated names are those used in Fig. 4. 'Group' = functional or taxonomic group: Oligo = aloricate, heterotrophic choreotrichs and oligotrichs; Mixo = mixotrophs; Tint $=$ tintinnids; Rapt $=$ heterotrophic raptorial litostomes; Other $=$ species not falling into the previous 4 groups

\begin{tabular}{|c|c|c|c|c|c|c|c|}
\hline \multirow[t]{2}{*}{ Taxon } & \multirow[t]{2}{*}{ Abbrev. } & \multirow[t]{2}{*}{ Group } & \multirow[t]{2}{*}{$\mathrm{N}$} & \multicolumn{2}{|c|}{ Abundance (cells l-1) } & \multirow{2}{*}{$\begin{array}{c}\text { Mean } \\
\text { depth }(m)\end{array}$} & \multirow{2}{*}{$\begin{array}{c}\text { Mean chl a } \\
\quad\left(\mu \mathrm{g} \mathrm{l}^{-1}\right)\end{array}$} \\
\hline & & & & Median & Maximum & & \\
\hline Lohmanniella oviformis & Loh_ovif & Oligo & 44 & 18 & 158 & 81 & 1.00 \\
\hline Leegaardiella sol & Lee_sol & Oligo & 40 & 9 & 123 & 68 & 0.95 \\
\hline Strombidium antarcticum & Strom_an & Mixo & 39 & 11 & 118 & 50 & 1.06 \\
\hline Leegaardiella ovalis & Lee_oval & Oligo & 35 & 11 & 63 & 73 & 0.98 \\
\hline Amphorides laackmanni & Amp_la & Tint & 33 & 21 & 1396 & 22 & 2.30 \\
\hline Oligotrich1 & Oligotr1 & Oligo & 29 & 7 & 67 & 59 & 1.66 \\
\hline Unidentified1 & unk1 & Other & 27 & 11 & 46 & 92 & 0.36 \\
\hline Strobilidium sp2 & Strob2 & Oligo & 23 & 8 & 112 & 77 & 1.97 \\
\hline Gymnozoum viviparum & Gym_vivi & Rapt & 22 & 8 & 59 & 34 & 2.04 \\
\hline Porpostoma notatum & Por_nota & Other & 21 & 4 & 14 & 149 & 0.22 \\
\hline Unidentified3 & unk3 & Other & 21 & 7 & 35 & 112 & 0.31 \\
\hline Pelagostrobilidium neptuni & Pelago_n & Oligo & 20 & 13 & 101 & 33 & 2.67 \\
\hline Oligotrich2 & Oligotr2 & Oligo & 18 & 4 & 18 & 95 & 0.63 \\
\hline Strobilidium multinucleatum & Strob_mu & Oligo & 18 & 5 & 38 & 87 & 0.55 \\
\hline Strombidium conicum & Strom_co & Mixo & 18 & 7 & 456 & 12 & 2.52 \\
\hline Haptorid sp1 & Hapt1 & Rapt & 15 & 4 & 14 & 89 & 0.33 \\
\hline Mesodinium rubrum & Meso_rub & Mixo & 14 & 16 & 38 & 35 & 0.84 \\
\hline Oligotrich3 & Oligotr3 & Oligo & 14 & 7 & 18 & 116 & 0.28 \\
\hline Spirostrombidium rhyticollare & Spiro_rh & Oligo & 13 & 7 & 263 & 12 & 4.02 \\
\hline Strombidium wulffi & Strom_wu & Oligo & 13 & 17 & 535 & 5 & 0.65 \\
\hline Tontonia antarctica & Tont_ant & $\operatorname{mixo}$ & 13 & 13 & 49 & 16 & 2.37 \\
\hline Didinium gargantua & Didinium & Rapt & 12 & 4 & 14 & 21 & 1.19 \\
\hline Tontonia gracillima & Tont_gra & Mixo & 12 & 6 & 63 & 46 & 2.17 \\
\hline Uronema sp. & Uron_sp & Other & 12 & 4 & 11 & 101 & 0.31 \\
\hline Strombidium sp6 & Strom6 & Oligo & 11 & 7 & 13 & 88 & 0.68 \\
\hline Laackmanniella naviculaefera & Laa_navi & Tint & 10 & 12 & 202 & 14 & 3.81 \\
\hline Strobilidium sp3 & Strob3 & Oligo & 9 & 8 & 17 & 69 & 0.47 \\
\hline Strombidium sp5 & Strom5 & Oligo & 9 & 7 & 48 & 74 & 0.50 \\
\hline Codonellopsis gaussi & Cod_gaus & Tint & 8 & 19 & 91 & 23 & 2.09 \\
\hline Strombidium dalum & Strom_da & Oligo & 8 & 4 & 21 & 26 & 2.57 \\
\hline Strombidium sp8 & Strom8 & Oligo & 8 & 8 & 29 & 13 & 2.14 \\
\hline Gymnozoum sympagicum & Gym_symp & Rapt & 7 & 8 & 17 & 32 & 0.52 \\
\hline Lagynophrya sp. & Lag_sp & Rapt & 7 & 4 & 7 & 126 & 0.20 \\
\hline Salpingella sp. & Salp_sp & Tint & 5 & 7 & 14 & 83 & 0.38 \\
\hline Strobilidium epacrum & Strob_ep & Oligo & 5 & 18 & 42 & 66 & 0.71 \\
\hline Codonellopsis biedermanni & Cod_bied & Tint & 4 & 14 & 20 & 58 & 1.92 \\
\hline Mesodinium pulex & Meso_pul & Rapt & 4 & 4 & 4 & 81 & 0.38 \\
\hline Pseudotontonia cornuta & Pseu_cor & Mixo & 4 & 4 & 8 & 59 & 0.55 \\
\hline Strombidium sulcatum & Strom_su & Oligo & 4 & 4 & 17 & 74 & 0.51 \\
\hline Strombidium sp3 & Strom3 & Oligo & 4 & 6 & 11 & 124 & 0.25 \\
\hline Askenasia sp. & Asken & Rapt & 3 & 7 & 7 & 64 & 0.29 \\
\hline Codonellopsis gaussi f. cylindroconica & Cod_cyl & Tint & 3 & 8 & 17 & 6 & 0.41 \\
\hline Dileptus sp. & Dileptus & Rapt & 3 & 7 & 7 & 32 & 0.46 \\
\hline Parafavella c.f. ventricosa & Paraf_ve & Tint & 3 & 4 & 4 & 64 & 0.24 \\
\hline Rhabdonellopsis sp. & Rhabd_sp & Tint & 3 & 4 & 8 & 60 & 0.64 \\
\hline Strobilidium sp1 & Strob1 & Oligo & 3 & 4 & 11 & 52 & 0.47 \\
\hline Strombidium sp4 & Strom4 & Oligo & 3 & 4 & 13 & 24 & 0.62 \\
\hline Strombidium sp7 & Strom7 & Oligo & 3 & 20 & 98 & 15 & 2.93 \\
\hline Cymatocylis convallaria & Cym_conv & Tint & 2 & 8 & 8 & 60 & 3.28 \\
\hline Frontonia frigida & Front & Mixo & 2 & 4 & 4 & 100 & 0.41 \\
\hline Monodinium balbianii & Mono_bal & Rapt & 2 & 6 & 8 & 88 & 0.25 \\
\hline Paractedoctema acruosa & Parac_ac & Other & 2 & 5 & 7 & 140 & 0.22 \\
\hline Strombidium crassulum & Strom_cr & Oligo & 2 & 4 & 4 & 10 & 0.71 \\
\hline Strombidium inclinatum & Strom_in & Oligo & 2 & 14 & 25 & 35 & 5.56 \\
\hline Strombidium sp2 & Strom2 & Oligo & 2 & 7 & 11 & 157 & 0.23 \\
\hline Uronema acutum & Uron_ac & Mixo & 2 & 7 & 13 & 11 & 0.58 \\
\hline Cymatocylis cristallina & Cym_cris & Tint & 1 & 2 & 2 & 20 & 0.37 \\
\hline
\end{tabular}


Table 4 (continued)

\begin{tabular}{|c|c|c|c|c|c|c|c|}
\hline \multirow[t]{2}{*}{ Taxon } & \multirow[t]{2}{*}{ Abbrev. } & \multirow[t]{2}{*}{ Group } & \multirow[t]{2}{*}{$\mathrm{N}$} & \multicolumn{2}{|c|}{ Abundance (cells $1^{-1}$ ) } & \multirow{2}{*}{$\begin{array}{c}\text { Mean } \\
\text { depth }(\mathrm{m})\end{array}$} & \multirow{2}{*}{$\begin{array}{l}\text { Mean chl } \\
\quad\left(\mu \mathrm{g} \mathrm{l}^{-1}\right)\end{array}$} \\
\hline & & & & Median & Maximum & & \\
\hline Cymatocylis incondita & Cym_inco & Tint & 1 & 8 & 8 & 20 & 6.31 \\
\hline Cymatocylis meridiana & Cym_meri & Tint & 1 & 4 & 4 & 60 & 0.58 \\
\hline Cymatocylis ovata & Cym_ovat & Tint & 1 & 2 & 2 & 20 & 0.37 \\
\hline Cymatocylis subconica & Cym_subc & Tint & 1 & 4 & 4 & 0 & 0.18 \\
\hline Haptorid sp2 & Hapt2 & Rapt & 1 & 4 & 4 & 0 & 0.43 \\
\hline Helicostomella subulata & Hel_subu & Tint & 1 & 4 & 4 & 120 & 0.25 \\
\hline Parafavella dilatata & Paraf_di & Tint & 1 & 2 & 2 & 20 & 0.37 \\
\hline Pelagohalteria sp. & Pelago_s & Oligo & 1 & 4 & 4 & 40 & 1.10 \\
\hline Strombidium emergens & Strom_em & Oligo & 1 & 4 & 4 & 40 & 0.64 \\
\hline Strombidium nov. spec. & Strom_no & Oligo & 1 & 4 & 4 & 40 & 0.64 \\
\hline Strombidium sp1 & Strom1 & Oligo & 1 & 7 & 7 & 300 & 0.19 \\
\hline Tintinnid 1 & Tint1 & Tint & 1 & 20 & 20 & 0 & 4.43 \\
\hline Unidentified2 & unk2 & Other & 1 & 4 & 4 & 180 & 0.11 \\
\hline
\end{tabular}

axis, and in fact there was the identical trend of negative correlations between mixotroph abundance and $\mathrm{NO}_{2}{ }^{-}+\mathrm{NO}_{3}{ }^{-}$or $\mathrm{PO}_{4}{ }^{3-}$ as for total ciliate abundance $\left(\mathrm{r}_{\mathrm{s}}=\right.$ -0.40 and -0.52 respectively; $p<0.01$ ). A third axis (not shown) was strongly correlated with the total depth of the station where the profile was taken $(\mathrm{r}=-0.57)$. Collectively, the first 3 axes of the PCA explained $42 \%$ of the species data $(22,12$ and $8 \%$, respectively) and $66 \%$ of the species-environmental factor correlations.

One small group that could be distinguished in the PCA was made up of the 3 species at the top end of the second PCA axis: Oligotrich1, Lohmanniella oviformis, Strobilidium sp3 (Fig. 4). All 3 species were common, appearing in at least 23 of 55 QPS samples. The 3 species were mid-water species, found at mean depths between 60 and $81 \mathrm{~m}$ (Table 2), with low picoautotroph abundance (775 to 836 cells $\mathrm{ml}^{-1}$ ), and at similar $\mathrm{NO}_{2}{ }^{-}+\mathrm{NO}_{3}{ }^{-}$and $\mathrm{NH}_{4}{ }^{+}$concentrations (17 to $22 \mu \mathrm{mol}$ $\mathrm{NO}_{2}{ }^{-}+\mathrm{NO}_{3}{ }^{-} \mathrm{l}^{-1} ; 1.3$ to $1.7 \mu \mathrm{mol} \mathrm{NH}_{4}{ }^{+} \mathrm{l}^{-1}$ ).

There were 52 samples in which species richness could be accurately estimated with QPS preparations and where species richness was $\geq 5$. These were used to construct SADs, and then to compare the measured data to theoretical distributions. Of the theoretical distributions (geometric, log-normal, log-series and zsm distributions), the geometric distribution gave the best fit to the species abundance curves for 30 samples, as measured by the AIC statistic. An example of this is the $40 \mathrm{~m}$ sample in profile P4 (Fig. 5A). The log-series distribution gave the best fit on 9 occasions (e.g. Fig. 5B), the log-normal for 7 samples (Fig. 5C) and the zsm distribution for 6 samples (Fig. 5D). There was a general trend that the geometric distribution gave the best fit to the relative abundances when the most abundant species was less dominant, i.e. when both the relative and absolute abundance of the most common species was low. The relative abundances of the most common spe- cies were 22, 36, 34 and $48 \%$ when the geometric distribution was ranked from best to worst fit; the median absolute abundances of the most abundant species were 19, 72, 114 and 267 ciliates $1^{-1}$ (Kruskal-Wallis test: $\mathrm{p} \leq 0.0004)$. The opposite trend, though weaker, was observed based on the ranking of the zsm distribution. When the zsm distribution gave the best fit, the dominant species made up $53 \%$ of the total abundance, or 46 ciliates $\mathrm{l}^{-1}$; when it gave the worst fit, the most abundant species was $28 \%$ of the total, or 23 ciliates $\mathrm{l}^{-1}$, a significant difference (relative abundance: $\mathrm{p}$ $=0.024$; absolute abundance: $\mathrm{p}=0.004$ ). No clear trend could be seen in species richness based on the ranking of the other distributions.

Using both settled samples and QPS to examine ciliates allowed a comparison of the two methodologies. Total ciliate numbers were consistently higher in the settled samples, on average 72 ciliates $\mathrm{l}^{-1}$, or $11 \%$, a significant difference (paired $t$-test: $p=0.006$ ). Regressing ciliate abundance as measured by the 2 methods produced the equation:

$$
\begin{gathered}
\text { Abundance }_{\mathrm{QPS}}=0.81 \times \text { Abundance }_{\text {Settled }}-9.73 \\
\left(\mathrm{R}^{2}=0.82, \mathrm{p}<0.0001\right)
\end{gathered}
$$

in which Abundance QPS $_{\text {and Abundance }}$ Settled are the abundances measured in the QPS and settled samples, respectively. The slope of the line was significantly $<1$ ( $p<0.001)$, indicating that the difference between the abundance estimates was not constant, but became less at higher abundances.

Surprisingly, there was no significant difference in the estimated species richness (paired $t$-test: $\mathrm{p}=0.071$ ) in the individual samples, although the total species richness was considerably higher in QPS samples (70 species or morphotypes in the QPS samples, 25 in the settled samples). Regressing species richness measured by the 2 methods produced a line with a slope 

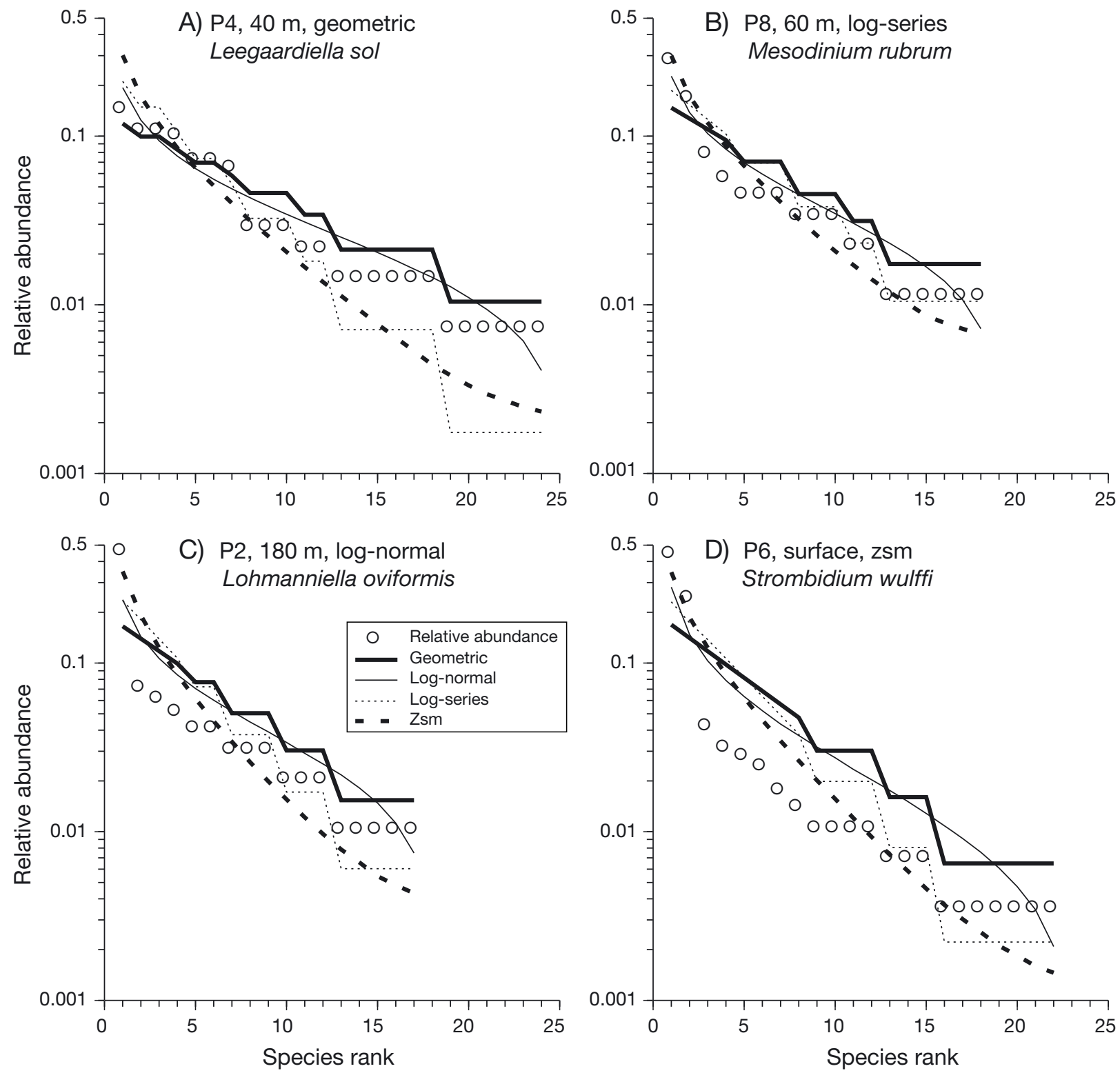

Fig. 5. Examples of the actual and estimated species abundance distributions, with the relative abundance of each species found in the sample plotted against its ranked abundance. In each panel, the station and depth of the sample for the distribution is given, along with the theoretical distribution giving the best fit to the data as well as dominant species in the sample. Zsm: zero-sum multinominal distribution

and intercept not significantly different from 1 and 0 , respectively ( $p>0.05$ ), indicating that the lack of difference in species richness estimates was consistent across the range of species richness observed in our study. The higher total species richness in the QPS samples was due to the higher taxonomic resolution this procedure allows: of the 70 morphotypes found in the QPS samples, 59 could be identified at least to genus, and 42 to species. There were also 2 morphotypes (a Strombidium species and a haptorid species) which appeared to be new. In contrast, in the settled samples, only a few obvious morphotypes such as
Strombidium conicum could be identified to species level, resulting in similar-appearing morphotypes from different samples being lumped together.

\section{DISCUSSION}

The ciliate community in the Bellingshausen and Amundsen Seas was a diverse one, given the generally extreme conditions - and given that the samples were taken at a time of rapidly declining productivity. Both temperature and chlorophyll a were low (mean tem- 
perature and chl $a$ in the mixed layer: $-0.5^{\circ} \mathrm{C}$ and $0.7 \mu \mathrm{g} \mathrm{chl} \mathrm{a} \mathrm{l}^{-1}$, respectively), with maximum values in the mixed layer reaching only $2.0^{\circ} \mathrm{C}$ and $4.5 \mu \mathrm{g} \mathrm{chl} \mathrm{a}$ $\mathrm{l}^{-1}$. Despite the extreme conditions, the ratio of ciliate biomass to chlorophyll biomass (2.1 in the mixed layer, 2.6 in the mid layers) was only moderately lower than that previously found in more temperate environments, where values mostly ranged from 2.8 to 5 (summarised in Dolan \& Marrase 1995).

As shown in many other studies, there was a dominance of aloricate oligotrich ciliates, both in terms of abundance and biomass (e.g. Garrison \& Buck 1989, Klaas 1997, Edwards et al. 1998, Santoferrara \& Alder 2009). Given the declining light levels during the Antarctic autumn, it was unexpected that mixotrophic species would make up $20 \%$ of total abundance in the mixed layer, similar to that found for the Mediterranean, an area with considerably higher light intensities (Pitta \& Giannakorou 2000, Pitta et al. 2001). However, mixotrophs have been found even during the Antarctic winter, contributing up to $10 \%$ of large ciliate abundance (Gowing \& Garrison 1992). Mixotrophs, as a group, had the same positive correlation with chl $a$ $\left(r_{\mathrm{s}}=0.72\right)$ and negative correlation with $\mathrm{NO}_{2}{ }^{-}+\mathrm{NO}_{3}{ }^{-}$ and $\mathrm{PO}_{4}{ }^{3-}$ as did total ciliate abundance. Individual mixotroph species were largely within the main cluster of species in the PCA (Fig. 4), although, consistent with their positive correlation with chl $a$ and higher proportion of total abundance in shallower depths, shifted to the right of the first (depth and chl a) PCA axis. It was therefore difficult to discern a trend which distinguished mixotrophic ciliate distributions from those of heterotrophic ciliates.

The 70 species found in the 55 samples where QPS was used appear to be close to the maximum that could be expected to be found: the rarefaction curves suggested that the true diversity was in the range of 77 to 90 species. Moreover, the slope of the richness-abundance curve (0.39) is almost exactly that found by Hillebrand et al. (2001) as a global pattern for ciliate species richness $(0.40)$, suggesting that the ciliate communities in the late summer Bellingshausen and Amundsen Seas are not species-poor, compared to more temperate habitats. However, the taxonomic data collected in the present study indicate that one cannot speak of an 'antarctic' ciliate community, at least in the pelagia. While some of the species found (e.g. Frontonia frigida, Tontonia antarctica) are specific to the Southern Ocean, many others are cosmopolitan (e.g. Mesodinium rubrum, Leegaardiella sol, Strombidium conicum; Montagnes et al. 1988, Petz 2005, Claessens et al. 2008). That there are Antarctic examples of common ciliate species should not be surprising, as geographically distant clones can have different temperature optima (Wickham \& Lynn 1990, Gächter \& Weisse
2006). However, common marine species have relatively little genetic diversity compared to geographically (e.g. rock pool or freshwater) isolated species (Katz et al. 2005), implying that the Antarctic Circumpolar Current provides the isolation required to foster high enough diversity within ciliate species to allow cold-water clones of cosmopolitan species.

It has been suggested that Southern Ocean microplankton communities exist in 1 of 2 phase states, pelagic and sea-ice (Priddle et al. 1996), and we were clearly sampling only the pelagic community. While Petz (2005) lists 161 known species from the Southern Ocean, many of these are associated with sea-ice. Petz et al. (1995) state that 55 of the 68 species they found were unique to sea-ice, and groups such as hypotrichs and stichotrichs for example, while typical of sea-ice communities, were absent from our samples. Only 2 species that Petz et al. (1995) list as common in sea-ice (Strombidium antarcticum and Gymnozoum viviparum) were also common in our pelagic samples (Table 4). With our samples being taken so late in the austral summer, it is not surprising that species typical of sea-ice communities were largely absent. Even in profile P5, closest to the ice edge (Fig. 1), the dominant species were Tontonia antarctica and Lohmanniella oviformis, both pelagic species. Thus the 70 species found in the current study, and, in particular, the projected 77 to 90 species expected to be found, represent an accurate picture of the true morphological diversity of the pelagic ciliate fauna of the Southern Ocean.

Comparing the diversity found in our samples to previous studies is difficult in that most previous work with good taxonomic resolution from the Southern Ocean has concentrated either on sea-ice and ice-edge communities or on tintinnids (e.g. Buck \& Garrison 1983, Garrison 1991, Wasik 1998). An annual cycle of sampling at Signey Island yielded 24 ciliate taxa, using Lugol's-fixed, settled samples, similar to the 25 morphotypes that could be identified in our Bouin's-fixed settled samples (Leakey et al. 1994). A total of 22 ciliate species were found in 36 samples from coastal stations in the Ross Sea, but samples were concentrated on a $20 \mu \mathrm{m}$ mesh and fixed in buffered formaldehyde, which is likely to result in considerable cell loss (Fonda Umani et al. 1998). Another coastal site yielded only 18 species even though protargol staining was used (Grey et al. 1997). The richness-chlorophyll and richness-abundance regressions presented in 'Results: Ciliate abundance and biomass patterns' would suggest that, at the maximum chlorophyll concentrations and ciliate abundances found by Grey (1997), between 23 and 29 species should have been found, which, in turn, suggests that the coastal stations visited by Grey et al. (1997) were relatively species-poor compared to the Bellingshausen and Amundsen Seas' stations sampled in the present study. 
Comparable data for the same geographic area, or even from different areas of the Southern Ocean at approximately the same time of year, particularly from open water sites, are rare in comparison to data from the austral spring and summer. The ciliate abundance found in our study was roughly similar to that found previously in the Bellingshausen Sea, although samples in the previous study were taken at the beginning of the austral summer (November-December, Edwards et al. 1998). In that study, there was a definite trend of increasing biomass in a transect from icecovered to open water, in an area east of our station P3. A study that included the southern reaches of the Drake passage in April found ciliate abundance and biomass (575 ciliates $\mathrm{l}^{-1}$ and $1.08 \mu \mathrm{g} \mathrm{C}^{-1}$, respectively) that were very similar to those found in the mixed layer in our study (Table 2). Interestingly, that study found much weaker correlations between ciliate abundance or biomass with temperature or chlorophyll, although data from both north and south of the polar front were grouped, which may have masked 2 separate trends (Santoferrara \& Alder 2009). Ciliate abundance and biomass in the Weddell Sea in March was similar to those found in the current study, though with generally lower chlorophyll values (Garrison \& Buck 1989). In summary, the ciliate abundance and biomass found in the current study are roughly comparable to previous work done at the same time of year, but chlorophyll was a better predictor of ciliate abundance and biomass in our study.

The PCA indicated that the composition of the ciliate community in the Bellingshausen and Amundsen Seas was driven by relatively few ecological factors. The first PCA axis, strongly correlated with chl $a$, explained $22 \%$ of the species distribution, and chl a alone could explain $48 \%$ of the variation in ciliate abundance. The slopes of the $\ln ($ abundance): $\ln (\mathrm{chl}$ a) and $\ln$ (biomass): $\ln (\mathrm{chl}$ a) regressions from our study were considerably steeper than those found for an oligotrophic region of the Mediterranean (Dolan \& Marrase 1995), indicating a greater dependence on productivity in our system. The comparable slopes were approximately 0.7 vs. 1.18 for $\ln ($ abundance) $: \ln (\mathrm{chl} a)$ and 0.8 vs. 1.19 for $\ln$ (biomass): $\ln (\mathrm{chl} a)$ (data redigitised from Fig. 4 in Dolan \& Marrase 1995). Thus, a productivity gradient, both between and within sampling stations, was the major driver of most aspects of the ciliate community (species composition, species richness, abundance and biomass). While positive productivityabundance or biomass relationships have been found within planktonic ciliate communities (Dolan \& Marrase 1995, Pitta et al. 2001, Zingel et al. 2002), this is not always the case, and the productivity-species richness relationship is less clear (Dolan et al. 1999, 2002, Claessens et al. 2010). For instance, strong positive relationships between tintinnid abundance and chl a have been found in the equatorial Pacific and the Mediterranean, but unlike the current study, no relationship between tintinnid species richness and chl a (Dolan et al. 2002, 2007). Thus, while productivity was a clear driver of ciliate abundance and biomass in our study, the positive productivity-richness relationship we found is far from being a general phenomenon. This could be partly due to the large effort necessary to obtain accurate estimates of aloricate ciliate species richness, but the work with tintinnids cited above had the requisite taxonomic resolution to find a productivity-richness relationship if one were present. What drives the species richness of marine ciliate communities remains to be determined.

A factor that was not measured in our study, predation, also has the potential to structure ciliate communities. Many copepods are selective predators on ciliates, choosing ciliates over phytoplankton prey and selecting among ciliate species (Jonsson \& Tiselius 1990, Atkinson et al. 2002). Both the adult and larval forms of the Antarctic krill Euphausia superba have the ability to impose significant mortality on ciliates, and while selection for ciliates over other prey has been shown, there is as yet little evidence for krill being able to structure the ciliate community through selective predation (Atkinson \& Snÿder 1997, Wickham \& Berninger 2007).

Dolan et al. (2007) examined the species-abundance patterns for tintinnids in the equatorial Pacific, and found that the log-series distribution most often gave the best fit to their data. In considerable contrast to these results, the geometric distribution gave the best fit to the majority of the species-abundance distributions from the Bellingshausen and Amundsen Seas, with the log-series distribution providing the best fit to only 9 of the 52 distributions. This is relevant in that the log-series distribution, and more often, the zsm distribution (which provided the best fit to 6 of our distributions) is cited as evidence of the neutral theory biodiversity providing the best explanation of species distributions (Hubbell 2001, Alonso \& McKane 2004, Dolan et al. 2007). According to the neutral theory, species assemblages are a collection of competitively similar species, assembled through random processes of immigration from a larger metacommunity, local extinction and speciation (Hubbell 2001). In contrast, the geometric distribution is often thought to be a result of niche partitioning, with each species taking the same percentage of available resources. If the competitive dominant species takes $20 \%$ of the available resources, the second best takes $20 \%$ of the remaining $80 \%$ and so on (Magurran 1988). This is expected to occur when relatively few environmental factors structure a community, although it is fre- 
quently acknowledged that multiple hypotheses can generate the same theoretical distribution (Magurran 1988, McGill et al. 2007). However, the hypothesis of a single environmental driver, as suggested by the geometric distribution, is consistent with the results of the PCA, which showed that a depth-productivity axis could explain $22 \%$ of total variance in the species distribution.

A pattern which emerged from the SADs is that when the geometric distribution gave the best fit to the data, there was no clear competitive dominant, with a fairly even distribution in the species-abundance pattern. However, there was a positive correlation to how well the geometric distribution fits the data, and the proportion of raptorial litostomes and 'other' ciliates in the samples (ciliates that were neither heterotrophic aloricate oligotrichs, tintinnids, litostomes, nor mixotrophs; $\left.r_{s}>0.42, p<0.01\right)$. The opposite was true for the zsm distribution. The zsm distribution gave a poor fit when the relative abundance of the rarest species, particularly those appearing only once in sample, was high, but also when the proportion of litostomes and 'other' ciliates was low. $\left(\mathrm{r}_{\mathrm{s}}<-0.41, \mathrm{p}<0.02\right.$; Fig. 5). The neutral theory has the assumption of 'hard symmetry', the explicit assumption that all species and individuals are equivalent (Alonso et al. 2008). This is consistent with the zsm distribution giving a poor fit when species with different feeding modes (i.e. filter-feeding oligotrichs and raptorial litostomes) are present. The geometric distribution is based on an assumption of niche partitioning, which would be more likely when different feeding modes were common. However, the proportion of different feeding modes can only explain so much about which distribution gave a better fit: the proportion of mixotrophs in the samples was not correlated with any distribution giving a better fit. Moreover, the dominance of a single species would appear to contradict the expectations of neutral theory, where species are competitively equivalent. An alternative explanation is, of course, that only a limited amount can be inferred by abundance distributions alone, and while observational patterns can generate hypotheses, experimental work is necessary to confirm or reject them.

The comparison of results obtained by QPS and settled samples suggests that Bouin's-fixed, settled samples are adequate to describe within-sample species richness, with no significant difference in the species richness measured by the 2 methods. There is a tradeoff in that, while QPS offers much higher resolution, there are fewer cells to be identified, and therefore a lower likelihood of finding rare species. The reasons for this are 2-fold: cells are lost during the processing steps, and the smaller surface area of the filter used in QPS compared to that of a settling chamber results in smaller sample volumes being used for QPS. When abundance and within-sample species richness (alpha diversity) is all that is required, then the minimum half day required to prepare 10 to 12 QPS samples is unnecessary. However, QPS has a clear advantage when evaluating regional (gamma) diversity. Marine plankton samples are often dominated by small oligotrichs, scuticociliates and prostomes (e.g. Claessens et al. 2008) which are difficult to differentiate between similar morphotypes within samples, a problem that is compounded when comparing between samples. Similarly, distinguishing between a new species and a similar, already described species requires a level of detail not available in settled samples. The unknown haptorid species found in our samples, for example, is evidently a new species, with characters (equitoral kinities, longitudinal kinity, microtubules in oral area) not visible in settled samples, that would most likely have led to the species being misidentified as a known species. Moreover, Lugol's-fixed samples tend to be more darkly stained than those fixed in Bouin's solution, making Lugol's-fixed samples still harder to identify. Conversely, using QPS alone is ill advised, as the method was shown to underestimate abundance substantially, with cells evidently being lost during the many staining and dehydration steps. That ciliates are frequently a critical group in aquatic food webs is clear. However, the drivers of ciliate diversity are not always self-evident, and without the combination of both good taxonomic and abundance/biomass data, it will be impossible to determine how the role of ciliates is modulated by the species composition of the ciliate community and smooth running.

Acknowledgements. We thank Captain U. Pahl and the crew of RV 'Polarstern' for their help and support, and cruise leader K. Gohl for the many stations and smooth running of Cruise ANT XXIII/4. T. Walter and E. Neubacher gave invaluable help during the cruise, and C. Lorenz and A. Pitt helped immeasurably with the packing before the cruise, and counting the samples afterwards. The manuscript was improved by the comments of U.-G. Berninger and 2 anonymous reviewers. This work was funded by the Austrian FWF grant P18822 to S.A.W.

\section{LITERATURE CITED}

Adler VA (1999) Tintinnoinea. In: Boltovskoy D (ed) South Atlantic zooplankton. Backhuys, Leiden, p 321-384

Agatha S, Riedel-Lorje JC (1997) Morphology, infraciliature, and ecology of halteriids and strombidiids (Ciliophora, Oligotrichea) from coastal brackish water basins. Arch Protistenkd 148:445-459

Agatha S, Struder-Kypke MC, Beran A, Lynn DH (2005) Pelagostrobilidium neptuni (Montagnes and Taylor, 1994) and Strombidium biarmatum nov. spec. (Ciliophora, Oligotrichea): phylogenetic position inferred from morphology, ontogenesis, and gene sequence data. Eur J Protistol 41:65-83 
Alonso D, McKane AJ (2004) Sampling Hubbell's neutral theory of biodiversity. Ecol Lett 7:901-910

Alonso D, Ostling A, Etienne RS (2008) The implicit assumption of symmetry and the species abundance distribution. Ecol Lett 11:93-105

Atkinson A, Snÿder R (1997) Krill-copepod interactions at South Georgia, Antarctica, I. Omnivory by Euphausia superba. Mar Ecol Prog Ser 160:63-76

Atkinson A, Meyer B, Stubing D, Hagen W, Schmidt K, Bathmann UV (2002) Feeding and energy budgets of Antarctic krill Euphausia superba at the onset of winter - II. Juveniles and adults. Limnol Oceanogr 47:953-966

Buck K, Garrison DL (1983) Protists from the ice-edge region of the Weddell Sea. Deep-Sea Res 30:1261-1277

Burkill PH, Edwards ES, Sleigh MA (1995) Microzooplankton and their role in controlling phytoplankton growth in the marginal ice-zone of the Bellingshausen Sea. Deep-Sea Res II 42:1277-1290

> Calbet A, Landry MR (2004) Phytoplankton growth, microzooplankton grazing, and carbon cycling in marine systems. Limnol Oceanogr 49:51-57

Christaki U, Jacquet S, Dolan JR, Vaulot D, Rassoulzadegan F (1999) Growth and grazing on Prochlorococcus and Synechococcus by two marine ciliates. Limnol Oceanogr 44:52-61

> Claessens M, Wickham SA, Post AF, Reuter M (2008) Ciliate community in the oligotrophic Gulf of Aqaba, Red Sea. Aquat Microb Ecol 53:181-190

> Claessens M, Wickham S, Post A, Reuter M (2010) A paradox of the ciliates? High ciliate diversity in a resource-poor environment. Mar Biol 157:483-494

Colwell RK, Coddington JA (1994) Estimating terrestrial biodiversity through extrapolation. Phil Trans R Soc Lond B 345:101-118

> Doherty M, Costas BA, McManus GB, Katz LA (2007) Culture-independent assessment of planktonic ciliate diversity in coastal northwest Atlantic waters. Aquat Microb Ecol 48:141-154

> Dolan JR, Marrase C (1995) Planktonic ciliate distribution relative to a deep chlorophyll maximum: Catalan Sea, NW Mediterranean, June 1993. Deep-Sea Res I 42:1965-1987

$>$ Dolan JR, Vidussi F, Claustre H (1999) Planktonic ciliates in the Mediterranean Sea: longitudinal trends. Deep-Sea Res I 46:2025-2039

> Dolan JR, Claustre H, Carlotti F, Plounevez S, Moutin T (2002) Microzooplankton diversity: relationships of tintinnid ciliates with resources, competitors and predators from the Atlantic Coast of Morocco to the Eastern Mediterranean. Deep-Sea Res I 49:1217-1232

> Dolan JR, Ritchie ME, Ras J (2007) The 'neutral' community structure of planktonic herbivores, tintinnid ciliates of the microzooplankton, across the SE Tropical Pacific Ocean. Biogeosciences 4:297-310

Edwards ES, Burkill PH, Sleigh MA (1998) Microbial community structure in the marginal ice zone of the Bellingshausen Sea. J Mar Syst 17:87-96

Foissner W, Chao A, Katz LA (2008) Diversity and geographic distribution of ciliates (Protista: Ciliophora). Biodivers Conserv 17:345-363

Fonda Umani S, Monti M, Nuccio C (1998) Microzooplankton biomass distribution in Terra Nova Bay, Ross Sea (Antarctica). J Mar Syst 17:289-303

> Froneman PW (2004) Protozooplankton community structure and grazing impact in the eastern Atlantic sector of the Southern Ocean in austral summer 1998. Deep-Sea Res II 51:2633-2643

> Gächter E, Weisse T (2006) Local adaptation among geographically distant clones of the cosmopolitan freshwater ciliate Meseres corlissi. I. Temperature response. Aquat Microb Ecol 45:291-300

Garrison DL (1991) Antarctic sea ice biota. Am Zool 31:17-33

Garrison DL, Buck K (1989) Protozooplankton in the Weddell Sea, Antarctica: abundance and distribution in the iceedge zone. Polar Biol 9:341-351

Garrison DL, Buck KR, Gowing MM (1993) Winter plankton assemblage in the ice edge zone of the Weddell and Scotia Seas: composition, biomass and spatial distributions. Deep-Sea Res I 40:311-338

> Garrison DL, Gibson A, Coale SL, Gowing MM, Okolodkov YB, Fritsen CH, Jeffries MO (2005) Sea-ice microbial communities in the Ross Sea: autumn and summer biota. Mar Ecol Prog Ser 300:39-52

Gowing MM, Garrison DL (1992) Abundance and feeding ecology of larger protozooplankton in the ice edge zone of the Weddell and Scotia Seas during the austral winter. Deep-Sea Res 39:893-919

Grey J, Laybourn-Parry J, Leakey RJG, McMinn A (1997) Temporal patterns of protozooplankton abundance and their food in Ellis fjord, Princess Elizabeth Land, eastern Antarctica. Estuar Coast Shelf Sci 45:17-25

> Hansen PJ (1991) Dinophysis - a planktonic dinoflagellate genus which can act both as a prey and a predator of a ciliate. Mar Ecol Prog Ser 69:201-204

Hankin RKS (2009) Introducing untb, an R package for simulating ecological drift under the unified neutral theory of biodiversity. J Stat Soft 22(12). Available at www.jstatsoft.org/v22/i12/

- Hillebrand H, Watermann F, Karez R, Berninger UG (2001) Differences in species richness patterns between unicellular and multicellular organisms. Oecologia 126:114-124

- Holmes RM, Aminot A, Kérouel R, Hooker BA, Peterson BJ (1999) A simple and precise method for measuring ammonium in marine and freshwater ecosystems. Can J Fish Aquat Sci 56:1801-1808

Hubbell SP (2001) The unified neutral theory of biodiversity and biogeography. Princeton University Press, Princeton, NJ

Johnson MD, Rome M, Stoecker DK (2003) Microzooplankton grazing on Prorocentrum minimum and Karlodinium micrum in Chesapeake Bay. Limnol Oceanogr 48:238-248

Jonsson PR, Tiselius P (1990) Feeding behavior, prey detection and capture efficiency of the copepod Acartia tonsa feeding on planktonic ciliates. Mar Ecol Prog Ser 60:35-44

> Katz LA, McManus GB, Snoeyenbos-West OLO, Griffin A, Pirog K, Costas B, Foissner W (2005) Reframing the 'Everything is everywhere' debate: evidence for high gene flow and diversity in ciliate morphospecies. Aquat Microb Ecol 41:55-65

Klaas C (1997) Microprotozooplankton distribution and their potential grazing impact in the Antarctic Circumpolar Current. Deep-Sea Res II 44:375-393

Kofoid CA, Campbell AS (1929) A conspectus of the marine and fresh-water Ciliata belonging to the suborder Tintinnoinea, with descriptions of new species principally from the Agassiz expedition to the eastern tropical Pacific 1904-1905. Univ Calif Publ Zool 35:1-403

- Leakey R, Fenton N, Clarke A (1994) The annual cycle of planktonic ciliates in nearshore waters at Signy Island, Antarctica. J Plankton Res 16:841-856

> Levinsen H, Nielsen TG (2002) The trophic role of marine pelagic ciliates and heterotrophic dinoflagellates in arctic and temperate coastal ecosystems: a cross-latitude comparison. Limnol Oceanogr 47:427-439

Levitus S (1982) Climatological atlas of the world oceans. US Department of Commerce, National Oceanic and Atmospheric Administration, Rockville, MD 
Lynn DH, Gilron GL (1993) Strombidid ciliates from coastal waters near Kingston Harbour, Jamaica (Ciliophora, Oligotrichia, Strombidiidae). J Mar Biol Assoc UK 73: 47-65

Lynn DH, Montagnes DJS (1988) Taxonomic descriptions of some conspicuous species of strobilidiine ciliates (Ciliophora: Choreotrichida) from the Isles of Shoals, Gulf of Maine. J Mar Biol Assoc UK 68:639-658

Lynn DH, Montagnes DJS, Small EB (1988) Taxonomic descriptions of some conspicuous species in the family Strombidiidae (Ciliophora: Oligotrichida) from the Isles of Shoals, Gulf of Maine. J Mar Biol Assoc UK 68:259-276

Magurran AE (1988) Ecological diversity and its measurement. Princeton University Press, Princeton NJ

Marie D, Partensky F, Vaulot D, Brussaard C (2001) Enumeration of phytoplankton, bacteria, and viruses in marine samples. Curr Protoc Cytom:Unit 11.11

May RM (1975) Patterns of species abundance and diversity. In: Cody ML, Diamond J (eds) Ecology and evolution of communities. Harvard University Press, Cambridge, MA, p 81-120

McGill BJ, Etienne RS, Gray JS, Alonso D and others (2007) Species abundance distributions: moving beyond single prediction theories to integration within an ecological framework. Ecol Lett 10:995-1015

McMinn A, Scott FJ (2005) Dinoflagellates. In: Scott FJ, Marchant HJ (eds) Antarctic marine protists. Australian Biological Resources Study \& Australian Antarctic Division, Canberra \& Hobart, p 202-250

Modeo L, Petroni G, Rosati G, Montagnes DJS (2003) A multidisciplinary approach to describe protists: redescriptions of Novistrombidium testaceum Anigstein 1914 and Strombidium inclinatum Montagnes, Taylor \& Lynn 1990 (Ciliophora, Oligotrichia). J Eukaryot Microbiol 50: 175-189

Montagnes DJS, Lynn DH (1987) A quantitative protargol stain (qps) for ciliates: method description and test of its quantitative nature. Mar Microb Food Webs 2:83-93

Montagnes DJS, Lynn DH, Stoecker DK, Small EB (1988) Taxonomic descriptions of one new species and redescriptions of four species in the family Strombidiiae (Ciliophora, Oligotrchida). J Protozool 35:189-197

Oksanen J, Kindt R, Legendre P, O'Hara B and others (2009) vegan: Community Ecology Package. $\mathrm{R}$ package version 1.15-2 (http://cran.r-project.org/)

Petz W (1999) Ciliophora. In: Boltovskoy D (ed) South Atlantic zooplankton. Backhuys, Leiden, p 265-319

Petz W (2005) Ciliates. In: Scott FJ, Marchant HJ (eds) Antarctic marine protists. Australian Biological Resources Study \& Australian Antarctic Division, Canberra \& Hobart, p 347-448

Petz W, Song W, Wilbert N (1995) Taxonomy and ecology of the ciliate fauna (Protozoa, Ciliophora) in the endopagial an pelagial of the Weddell Sea, Antarctica. Stapfia 40:1-233

Pitta P, Giannakorou A (2000) Planktonic ciliates in the oligotrophic Eastern Mediterranean: vertical, spatial distribution and mixotrophy. Mar Ecol Prog Ser 194:269-282

Pitta P, Giannakourou A, Christaki U (2001) Planktonic ciliates in the oligotrophic Mediterranean Sea: longitudinal

Editorial responsibility: Urania Christaki, Wimereux, France trends of standing stocks, distributions and analysis of food vacuole contents. Aquat Microb Ecol 24:297-311

Priddle J, Leakey RJG, Archer SD, Murphy EJ (1996) Eukaryotic microbiota in the surface waters and sea ice of the Southern Ocean: aspects of physiology, ecology and biodiversity in a 'two-phase' ecosystem. Biodivers Conserv 5: 1473-1504

Putt M, Stoecker DK (1989) An experimentally determined carbon:volume ratio for marine 'oligotrichous' ciliates from estuarine and coastal waters. Limnol Oceanogr 34: 1097-1103

Sanders RW (1991) Mixotrophic protists in marine and freshwater ecosystems. J Protozool 38:76-81

Sanders RW, Wickham SA (1993) Planktonic protists and metazoa: predation, food quality and population control. Mar Microb Food Webs 7:197-223

Santoferrara L, Alder V (2009) Abundance trends and ecology of planktonic ciliates of the south-western Atlantic (35$63^{\circ} \mathrm{S}$ ): a comparison between neritic and oceanic environments. J Plankton Res 31:837-851

SAS Institute (1989) SAS/STAT users guide, version 6, 4th edn. SAS Institute, Cary, NC

Skibbe O (1994) An improved quantitative protargol stain for ciliates and other planktonic protists. Arch Hydrobiol 130: 339-347

Skovgaard A, Legrand C (2005) Observation of live specimens of Pseudotontonia cornuta (Ciliophora: Oligotrichida) reveals new distictive characters. J Mar Biol Assoc UK 85:783-786

Song W, Wilbert N (2000) Ciliates from Antarctic sea ice. Polar Biol 23:212-222

Steidinger KA, Tangen K (1977) Dinoflagellates. In: Tomas CR (ed) Identifying marine phytoplankton. Academic Press, San Diego, CA, p 387-584

Stoecker DK, Gallager SM, Langdon CJ, Davis LH (1995) Particle capture by Favella sp. (Ciliata, Tintinnina). J Plankton Res 17:1105-1124

Suzuki T, Song W (2001) A redescription of Tontonia cornuta (Leegaard, 1915) comb. nov., a planktonic oligotrichous ciliate (Ciliophora: Oligotrichia) from the northern Pacific Ocean. Hydrobiologia 457:119-123

Ter Braak CJF (1986) Canonical correspondence analysis: a new eigenvector technique for multivariate direct gradient analysis. Ecology 67:1167-1179

Wasik A (1998) Antarctic tintinnids: their ecology, morphology, ultrastructure and polymorphism. Acta Protozool 37: $5-15$

> Weisse T, Müller H, Pinto-Coelho RM, Schweizer A, Springmann D, Baldringer G (1990) Response of the microbial loop to the phytoplankton spring bloom in a large prealpine lake. Limnol Oceanogr 35:781-794

Wickham SA, Berninger UG (2007) Krill larvae, copepods and the microbial food web: interactions during the Antarctic fall. Aquat Microb Ecol 46:1-13

Wickham SA, Lynn DH (1990) Relations between growth rates, cell size and DNA content in colpodean ciliates (Ciliophora: Colpodea). Eur J Protistol 25:345-352

Zingel P, Huitu E, Mäkelä S, Arvola L (2002) The abundance and diversity of planktonic ciliates in 12 boreal lakes of varying trophic state. Arch Hydrobiol 155:315-332

Submitted: April 29, 2010; Accepted: October 12, 2010

Proofs received from author(s): December 22, 2010 